\title{
Models of procedural management of criminal prosecution in Russia and foreign countries
}

\author{
Elena Sergeevna Alekseeva, Fedor Yurevich Vasilev, Nataliya Viktorovna Lantukh, \\ Maksim Anatolevich Makarenko, and Sofya Dmitrievna Shestakova*
}

Saint Petersburg University of the Ministry of Internal Affairs of Russia, Department of Criminal Procedure, Saint Petersburg, Russia

\begin{abstract}
The article is devoted to the study of foreign and Russian models of procedural management of criminal prosecution. The authors propose general theoretical approaches that made it possible to conduct their systemic analysis and comparison. Prerequisites for the research: the necessity to reform legislation in terms of procedural management of criminal prosecution, optimize the distribution of procedural functions between the official subjects of criminal procedural activity. Purpose of the research: to create a theoretical model of procedural management of criminal prosecution based on historical and comparative-legal analysis of Russian and foreign structures. Results and novelty: An abstract (theoretical) model of managing criminal prosecution is a set of procedural parameters reflecting: 1) The coincidence of the head of the criminal prosecution and the subject who initiated it, or the absence of such a coincidence; 2) Unity or plurality of subjects of procedural management, their subordination; 3 ) The presence or absence of a combination of managerial powers with supervisory and control powers; 4) Correlation of the management with the procedural independence of the subject conducting the criminal prosecution; 5) The coincidence of the head of the criminal prosecution and the public prosecutor in one person; 6) Freedom and limits of disposal of the subject of criminal prosecution, and criminal action; 7) The powers of the head of the criminal prosecution to terminate the case and withdraw the charges. The scientific novelty of the research is determined by the range of analyzed problems, taking into account the changes that occur in the field of criminal proceedings, as well as the need for an optimal distribution of powers in the procedural management of criminal prosecution.
\end{abstract}

Keywords: pre-trial proceedings, criminal prosecution, prosecutor, procedural guidance

\section{Introduction}

In the Russian criminal process, the issues of the mechanism of the management of criminal prosecution, as well as its correlation with the functions of control and supervision, remain relevant and debatable. The distribution of powers between the heads of the investigation

*Corresponding author: shestakova_sofia@mail.ru 
departments, the heads of the inquiry, and the prosecutor, as well as the procedures associated with it, is controversial.

In the study, general scientific and specific scientific methods of cognition: historical, logical, systemic-structural, and comparative-legal methods, the method of legal modeling, etc. are used. The study is based on the conceptual provisions of the science of criminal procedure.

In Russia, since a certain time, there has been a redistribution of powers in the procedural management of criminal prosecution and two models of it have developed, which are performed by various subjects in the established volume and limits. Based on the analysis of foreign experience, its generalized model is made.

\section{Discussion}

\subsection{Theoretical bases}

In most of the states covered by the study, the prosecutor acts as the main head of the criminal prosecution, has the exclusive right to bring charges, refuse criminal prosecution, terminate proceedings, and conclude a pre-trial agreement. Performing the function of procedural management allows him or her at any time of pre-trial proceedings to take decisions on the direction of the further course of the investigation, the use of coercive measures, to participate in investigative actions, to give the police separate orders and instructions, as well as to coordinate its actions [1]. This function is also known to individual states where the prosecutor's office cannot conduct an investigation directly (France, Spain, etc.) [2]. In the Russian criminal procedure, it is distributed between the prosecutor and the head of the investigative body, the heads of the bodies and departments of inquiry. At the same time, in science, there is no unity in the delimitation of such concepts as the prosecutor's supervision, departmental control, and procedural management [3, pp. 92-97].

Exercising procedural control, authorized officials establish whether the controlled activity complies with both the law and other requirements, in particular, those that determine the set tasks and methods of solving them. In Russia, departmental control is entrusted to the head of the investigative body, heads of bodies and departments of inquiry. As practice shows, it is partly conducted by the prosecutor while supervising, and this gives it a supra departmental character and brings attention to the issues of legality [4, p. 109].

\subsection{Historical aspect}

At the beginning of the 18th century, an investigative apparatus began to take shape in the Russian Empire. With the adoption of the Charter of Criminal Procedure in 1864, the institution of judicial investigators was established, the prosecutor was endowed with special powers to supervise their activities, as well as the rights of a public prosecutor [5]. However, the investigator, being at the court and under the supervision of the prosecutor, did not have a supervisor over himself or herself, capable of limiting his or her independence. During the Soviet period, the role of the prosecutor in criminal proceedings increased, and the prosecutor became the main head of criminal prosecution. This was not affected by endowing the head of the investigative department with part of their powers in accordance with the 1960 Criminal Procedure Code of the RSFSR [6, p. 25]. In the post-Soviet period, judicial control was introduced in pre-trial proceedings, which entailed a reduction in the supervisory powers of the prosecutor. The possibility of his or her management in the investigation was ruled out when the head of the investigative body appeared in 2007, but at the same time, it remained in relation to the inquiry. In fact, there was a differentiation of the management of criminal 
prosecution into two models [7, p. 48]: 1) multilevel - retained the previous mechanism, applies to the inquiry and includes two levels of influence: intradepartmental one - comes from the heads of bodies and departments of inquiry; supra departmental - comes from the prosecutor; 2) one-level - has a relation to the investigator, all powers for procedural management are concentrated in the head of the investigative body.

\subsection{Commonwealth of independent states}

In the post-Soviet space, on the basis of the "inherited" union model of managing criminal prosecution, the former republics created their own models. Their legislators were guided by both Russian and German experience, including such an element of the German model of pre-trial proceedings as the balance of the procedural dominance of the prosecutor and the procedural independence of the person conducting the proceedings $[8, \mathrm{p} .8]$. The scientific approaches implemented in other states were taken into account, representing both the Romano-Germanic and Anglo-Saxon legal families.

The analysis of the current models in the CIS allows coming to the following conclusions:

1) It is characteristic (not for Russia) to endow the prosecutor with both the right to initiate criminal prosecution and its procedural management. Thus, according to the Criminal Procedure Code of Azerbaijan [9], he or she is the one who bears full responsibility for the execution of laws by the investigating bodies, represents them in courts, makes procedural decisions on the current cases, and performs individual investigative actions.

2) The Russian head of the investigative body has the broadest powers, both of a supervisory and a managerial nature. However, in other states, there is a tendency to expand the circle of heads in criminal prosecution, while maintaining the dominant role of the prosecutor.

3) The prosecutor, as a rule, is considered not only as the head of the criminal prosecution but also as the subject of supervision of legality in pre-trial proceedings.

4) Much less attention is given to the need to ensure the procedural independence of the investigator (in contrast to Russia) in other CIS countries. However, according to the Criminal Procedure Code of Kazakhstan [10], the investigator makes decisions independently. The instructions of the head of the investigation department should not limit his or her independence, and he or she has no right to cancel the decisions of the investigator, he or she is forced to address the prosecutor for this. In the Criminal Procedure Code of Kyrgyzstan [11], the head of the investigation is prohibited to give instructions to the investigator if they infringe on his or her independence.

5) Prosecutors in the CIS countries freely resolve issues related to both the termination of criminal cases and the formation of charges in pre-trial proceedings. The Russian prosecutor is limited in this in cases investigated by investigators. In most states, including Russia, the coincidence of the head of the criminal prosecution and the public prosecutor is permitted. Only the Criminal Procedure Code of the Republic of Azerbaijan establishes a ban on its maintenance to the prosecutor who was in charge of the investigation.

\subsection{European countries}

In the countries of the continental legal system, there is no single universal model for the management of criminal prosecution. Nevertheless, as a rule, both the police and the prosecutor's office can initiate criminal proceedings. In contrast to Russia, in Europe, the moment of initiating a criminal case is not associated with the issuance of a special procedural act. However, for example, according to the German Tax Code, a case is considered open from the moment the finance department, police, prosecutor's office or criminal court takes a measure aimed at incriminating someone of committing a crime [11]. 
Despite the right of the prosecutor to initiate a criminal case, further investigation may be entrusted to other bodies. Thus, depending on the complexity of the case and the current investigative situation in Sweden, it is conducted directly by the police under the management of a prosecutor or a police officer. The prosecutor conducts it in cases where there is a suspect in the case. In his or her absence, when investigating less complex cases, - it is done by the police. In Germany, however, the prosecutor alone is in charge of the investigation. In serious cases, investigations are conducted by investigators of the prosecutor's office [13].

At the final stage of the investigation, the prosecutor assesses the sufficiency of the collected evidence and determines the further progress of the case. According to the German Code of Criminal Procedure, if, as a result of the investigation, sufficient grounds for bringing a public accusation are established, the prosecutor's office presents it by filing the indictment in court, if not, it terminates the proceedings. In Sweden, if there is sufficient evidence to prove the guilt of the person, the prosecutor initiates proceedings before the trial. In the judicial stages, the function of the prosecutor's office, which is typical for European countries, is maintaining the public prosecution.

\subsection{The United States of America}

The analysis of this model involves the study of both federal legislation [13] and the laws of the states $[14,15]$. It is due to the adversarial type of the American procedure, based on the principle of the expediency of criminal prosecution and the broad discretionary powers of the representative of the Attorney Service (analogous to the European prosecutor's office) predetermined by it - the exclusive and sovereign manager of the initiation of criminal prosecution, its direction and further fate [16]. The model is characterized by the following:

1) The monopoly right of the attorney to initiate criminal prosecution;

2) The unity of the subjects of the management of criminal prosecution. The chiefs of the police only provide for the collection of evidence, conduct searches and arrests, etc., perform organizational functions and do not exert any influence on the fate of the case;

3) Due to the absence of an admixture of supervisory and control powers to the powers to manage criminal prosecution, it exists in its pure form. The actions of the attorney, even outwardly similar to the supervisory actions - the expression of consent for the police to address to court for an arrest warrant, search warrant, etc. are not an additional means of ensuring constitutional rights and freedoms of an individual, but exclusively a manifestation of expediency in the sense of the coordination of actions of the police and other subjects of criminal prosecution with the intentions of its head, since by giving such consent, he or she expresses his or her intention to continue the persecution, and in the absence of such an intention, he or she will simply refuse it and it will thereby be terminated;

4) The subject conducting the criminal prosecution lacks procedural independence in its Russian sense. He or she is only a tool in the hands of the head, aimed at the goal and used at his or her own discretion to achieve it;

5) Inseparability of criminal prosecution and its management at all stages of criminal proceedings, including public prosecution in court, as well as the appeal against court decisions. The prosecution in court, as a rule, is supported by the same attorney who initiates it;

6) The attorney's wide, almost unlimited freedom to dispose of a criminal action, the subject of the charge: from the autocratic decision on the initiation of criminal prosecution, artificial understatement of the volume and severity of charges in connection with concluding plea deals to refusal to prosecute, as well as on the grounds of its further inexpediency;

7) The absolute right of the head of the criminal prosecution to terminate it, refusal to prosecute in court - nolle prosequi. The requirement, predetermined by the federal law and the law of some states, for a court to approve a prosecutor's waiver of prosecution, which is 
filed after making an indictment or after being transferred to the court by the grand jury, has a formal nature: the court usually approves it.

\section{Conclusion}

As the research shows, there are several well-established models of procedural management of criminal prosecution. They can be characterized through the presented system of parameters that open up the possibility for modeling. An attempt was made to test it by analyzing the models that have developed in the countries of the Anglo-Saxon and RomanoGermanic legal systems, in Russia and other CIS countries. The possibility of using the modeling method as a reliable tool in conducting scientific research on the stated problems is shown.

\section{References}

1. Yu.P. Borulenkov, Russian Investigator, 10 (2013)

2. S.P. Sherba, N.V. Dodonov, Zakonnost, 6, 53-57 (2011)

3. E.K. Kutuev, Ugolovno-protsessualnoe pravo (Ugolovnyi protsess) [The Law of Criminal Procedure (Criminal procedure)] (Direct-Media, Moscow, Berlin, 2020)

4. G.N. Korolev, Prokurorskoe ugolovnoe presledovanie v rossiiskom ugolovnom protsesse [Prosecutor's criminal prosecution in the Russian criminal process] (Yurlitinform, Moscow, 2006)

5. T.D. Dudorov, Legal Science, 4, 14 (2014)

6. N.N. Polyansky, Ugolovno-protsessualnyi kodeks RSFSR (Sravnitelnyi ocherk staroi i novoi redaktsii kodeksa) [Code of Criminal Procedure of the RSFSR (Comparative essay of the old and new versions of the code)] (Moscow, 1923)

7. M.A. Makarenko, Ugolovno-protsessualnye pravootnosheniya s uchastiem prokurora [Criminal-procedural legal relationships with participation of the prosecutor: monograph] (Saint Petersburg University of the Ministry of Internal Affairs of Russia, Saint Petersburg, 2019)

8. S.G. Konovalov, Elementy germanskoi modeli dosudebnogo proizvodstva $v$ ugolovnom protsesse postsovetskikh gosudarstv [The elements of the German model of pre-trial proceeding in criminal process of post-Soviet states], Abstract of a $\mathrm{PhD}$ thesis (Lomonosov Moscow State University, Moscow, 2018). Accessed on: November 11, 2020. [Online]. Available:

https://www.msal.ru/upload/main/00disser/2016/Konovalov/Диссертация\%20Конова лов.pdf

9. Ugolovno-protsessualnyi kodeks Azerbaidzhanskoi Respubliki [Criminal Procedure Code of the Azerbaijan Republic] (2000). Accessed on: December 2, 2020. [Online]. Available: https://online.zakon.kz/document/?doc_id=30420280

10. Ugolovno-protsessualnyi kodeks Respubliki Kazakhstan [Criminal Procedure Code of the Republic of Kazakhstan] (2014). Accessed on: December 2, 2020. [Online]. Available: https://online.zakon.kz/Document/?doc_id=31575852

11. Ugolovno-protsessualnyi kodeks Kyrgyzskoi Respubliki [Criminal Procedure Code of the Kyrgyz Republic] (2017). Accessed on: December 2, 2020. [Online]. Available: https://online.zakon.kz/document/?doc_id=36313326

12. U. Hellman, Vvedenie v ugolovno-protsessualnoe pravo FRG [Introduction to the law of criminal procedure of FRG], in P. Golovnenkov, N. Spitsa (eds.), Ugolovno- 
protsessualnyi kodeks Federativnoi Respubliki Germaniya - Strafprozessordnung (StPO) - Nauchno-prakticheskii kommentarii i perevod teksta zakona [Criminal Procedure Code of the Federal Republic of Germany - Strafprozessordnung (StPO) Scientific and practical commentary and translation of the text of the law] (Potsdam University, Potsdam, 2012)

13. Federal Rules of Criminal Procedure. Accessed on: December 9, 2020. [Online]. Available: www.law.cornell.edu

14. Pennsylvania Code - Title 234 Rules of Criminal Procedure. Accessed on: December 9, 2020. [Online]. Available: www.pacodeanbulletin.gov

15. 2016 California Penal Code - Part 2 - of Criminal Procedure. Accessed on: December 9, 2020. [Online]. Available: www.law.justia.com

16. R. del Carmen, Criminal Procedure: Law and Practice (Wadsworth Publishing Co. Inc., Belmont, 1997) 